\title{
Adoption of Recommended Plant Protection Measures for the Management of Major Coconut Pests by Coconut Growers in Kurunegala District, Sri Lanka
}

\author{
W.G. Ruvani Subhathma ${ }^{1}$
}

\begin{abstract}
Coconut production in Sri Lanka is threatened by pest and diseases. Therefore, different remedial measures have been introduced by Coconut Research Institute (CRI) to safeguard the plantations. This study was carried out to determine the adoption of recommended plant protection measures to manage major pests of coconut by the growers in different land categories. The growers were selected from Kurunegala district, which is the major coconut growing district in coconut triangle in Sri Lanka. Findings of the study revealed that more than 70 percent of the growers in all land categories above 2Ac had adopted technologies recommended by CRI to control black beetle. Technology adoption was around 60 percent for red weevil control, around 30 percent for coconut mite and around 65 percent for plesispa beetle. It was also noted that the decision making on the adoption of different technologies is affected by the perceptions of the growers. Growers' perception was determined by two factors, information receiving sources and occurrence of pest attacks in their fields. Further, it was found that the growers are having limited access to latest technologies in pest control. In addition, the study revealed that unawareness of technologies and low attention for coconut farming was the two major reasons for poor adoption of the recommended technologies. It is concluded that coconut growers in Kurunegala district require more awareness regarding recommended plant protection measures to manage major coconut pests and strengthen extension programes.
\end{abstract}

Key words: Technology adoption, pest, coconut, grower perceptions, coconut growers

\section{Introduction}

Coconut (Cocos nucifera L.) is one of the most widely grown plantation crop in the tropics. It spreads over 400,000 ha of land area in all administrative districts of Sri Lanka except those at the elevations beyond 750m above mean sea level (Central Bank Sri Lanka, 2016; Somasiri et al., 1994). The total nut production was 3056 million in 2015 (Central Bank Sri Lanka, 2016). Coconut is considered as a crop of multipurpose use providing food, shelter, oil, medicine, fuel, building materials and beverage. Therefore, coconut is interwoven with the lives of local people and considered as a "Tree of heaven" or the "Tree of life". Coconut industry generates employment for nearly 500,000 people while contributing to nearly 0.7 percent of gross domestic production and 1.0 percent of foreign exchange earnings (Central Bank Sri Lanka, 2016; Liyanage, 1999). Coconut is an important source of dietary energy for Sri Lankans as well as other people all over the globe. The coconut endospermbased (kernel) products are essential components in Sri Lankan diet, which provides about 22 percent per capita calorie requirement. Consequently, about 70 percent of the annual coconut production is used for local consumption leaving nearly 30 percent for the coconut-based industries.

\footnotetext{
${ }^{1}$ Technology Transfer Officer, Coconut Research Institute, Sri Lanka.

E-mail: ruvanigodage@gmail.com
} 
Coconut is highly concentrated in the coconut triangle which includes Kurunegala, Gampaha and Puttalum districts covering about $75 \%$ of the coconut growing lands in the country (Somasiri et al., 1994). Coconut occupies more than 12,000 ha in Galle, 14,000 ha in Matara and 20,000 ha in Hambantota districts in the Southern province forming a "mini coconut triangle" (Coconut statistics, 2008).

The coconut sector in Sri Lanka shows a commendable growth during the last few years. However, steady economic growth of this sector is affected by many factors such as fragmentation of coconut lands, unfavourable weather conditions and pests and disease incidences. Introduction of serious pests and diseases aggravates this situation. For example, introduction of coconut mite, Aceria guerreronis Keifer in late 1997 was considered as a major threat to the coconut production of Sri Lanka (Fernando et al., 2007) causing about 2\% annual national crop losses (Wickramananda et al., 2007). Similarly Weligama Leaf Wilt disease that was spread in over 40,000 ha in the Southern province was the most serious threat to coconut industry in the recent past. In addition, red weevil (Rhynchophorus ferrugineus Olivier), black beetle (Oryctes rhinoceros L.), plesispa beetle (Plesispa reichi (Chapuis)) and coconut caterpillar (Opisina arenosella Walk) are considered as major pests in coconut (Ranasinghe et al., 2006). Among them plesispa beetle attacks only for coconut seedlings.

In order to increase the productivity levels of the coconut farms, the level of adoption of farm practices has to be increased. For that purpose, knowledge of the recommended technologies is a pre-requisite. The adoption of any new technology depends on the individual development and the acceptance. Therefore, as generally it is observed that all growers do not use recommended practices. Some recommendations record very slow rate of adoption and some may readily adopted than the other. The differential rate of adoption of new technologies by farmers is mainly depends on personal and socio-economic characteristics of farmers, as reported by Basaram and Cofenor (1968) and Rogers (1968).
There are recommended plant protection technologies are already introduced by the Coconut Research Institute to manage these pest problems in growers' fields. However, the problems are still remained and many coconut growers are not aware of those remedial measures and/or reluctant to adopt those measures due to uncertainty of the outcome. Therefore, this study was conducted aiming to identify the factors affecting the adoption of plant protection measures and constraints experienced by coconut growers while adopting those techniques. Further, this study may be useful to the extension functionaries in addressing the problems of coconut growers and it may help the future researchers to get an insight into the problem of adoption of recommended plant protection measures in coconut crop.

\section{Methodology:}

\section{Study area and sampling:}

This study was conducted as sociological survey method and farmer fields were selected from Kurunegala district, which is one of the major districts in the coconut triangle of Sri Lanka (Figure 1). Kurunegala district was located in North Western province of Sri Lanka and it comprised of two main agro ecological zones as intermediate and dry zone.

More than 250,000 coconut growers were already established throughout the district.

The sample size was determined using optimal allocation according to total holding size in each land category and according to stratified random sampling technique as $<2 \mathrm{Ac}, 2-5 \mathrm{Ac}, 5-$ $20 \mathrm{Ac}$ and $>20 \mathrm{Ac}$. The relevant sample sizes were as $35,50,20$ and 12 respectively.

\section{Data collection:}

A total of 117 coconut growers were selected randomly covering whole district. The data and information required for the study was collected from direct and indirect sources. The primary data such as demographic factors, occurrence of a pest attack, use of different recommended technologies, etc. was collected with a semi-structured questionnaire, 
administered and asked for the household heads in the selected community. Secondary data (recommended plant protection techniques) was collected from Coconut Research Institute. The questions were derived to get information regarding most influential factors for adoption of recommended plant protection measures by the Coconut Research Institute (CRI) to control major coconut pests such as black beetle, red weevil, coconut mite and plesispa beetle.

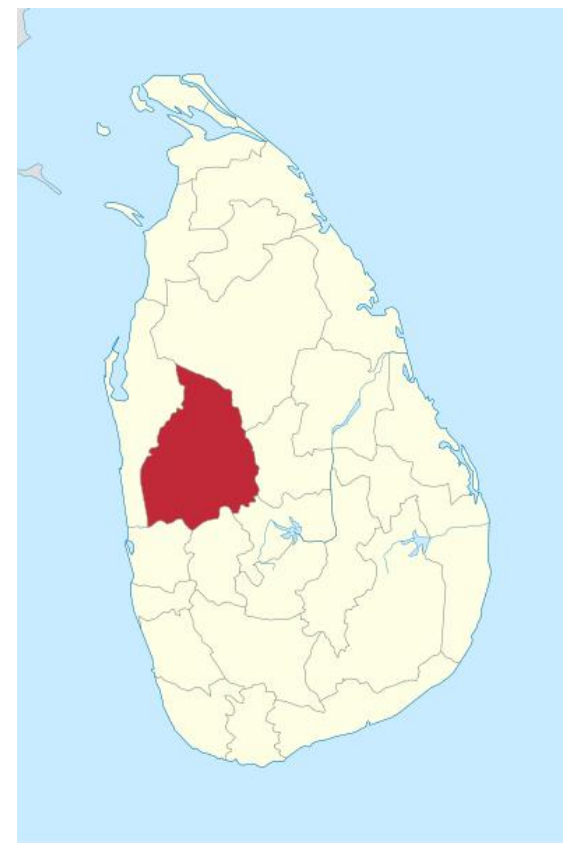

Figure 1. Map of the proposed study area of Kurunegala district

Source: (Department of Census and Statistics, 2002)

\section{Results and Discussion}

\section{Demographic characteristics of the respondents}

Decision making of farmers is considered to be influenced by demographic factors (Ghulam Ali Jariko et al., 2011) in addition to recommended technologies introduced to manage major coconut pests. Those are age, education level and gender.

The demographic characters of coconut growers in selected sample in Kurunegala district is shown in table 1 .
The average age of growers in Kurunegala district was 55.2 years. The majority of the coconut growers in Kurunegala district have secondary level (Up to G.C.E. (A/L)) educational background. The majority of the growers were male.

\section{Comparison on application of recommended technologies}

Average percentage of recommended technologies applied by the growers to control four different pest species in different land categories are shown in table 2.

According to the table 2, more than 70 percent of the growers in all land categories above 2 Ac are applied the recommended techniques introduced by the CRI to control black beetles. Application of recommended control measures for red weevils is around 60 percent, 30 percent for coconut mites and 65 percent for plesispa beetles (Table 2). It was noted that the adoption of recommended control measures were very poor in growers having acreage of less than two $(<2 \mathrm{Ac})$.

In coconut sector, management system currently being practiced for control pest problem is "Integrated Pest Management method". This method is highly effective and economically feasible for growers (Peiris, et al., 2006).

The table 3 shows that the variation of technology adoption to control coconut black beetles in with different land size.

Under the preventive measures, application of coal tar or used engine oil was practiced against black beetles by majority (55\%) of the farmers in all categories of land. It was followed by placing of naphthalene balls and maintaining better field sanitation (Table 3). When considering the control methods, most of the farmers in all land categories are mostly adopted for "application of carbofuran granules" to kill beetles, in addition to "use of pointed metal hook to remove beetles". However, the practice of pheromone trap is very poor $(14 \%$ only in 5-20Ac land category). 
Table 1: Demographic characteristics of the selected sample of growers according to land holding size

\begin{tabular}{|c|c|c|c|c|c|}
\hline Grower characteristics & \multicolumn{4}{|c|}{ Farm size categories } & \multirow{2}{*}{ All } \\
\cline { 2 - 5 } & $<\mathbf{2 ~ A c}$ & $\mathbf{2 - 5} \mathbf{~ A c}$ & $\mathbf{5}-\mathbf{2 0}$ Ac & $>\mathbf{2 0}$ Ac & \\
\hline Age (years)* & 53.52 & 55.24 & 59 & 54 & 55.2 \\
SD & $(11.03)$ & $(8.51)$ & $(11.24)$ & $(13.32)$ & $(10.3)$ \\
\hline Education Level & 1 & 2 & 2 & 2 & 2 \\
& $(1.49)$ & $(2.22)$ & $(1.8)$ & $(2.33)$ & $(1.94)$ \\
\hline \% Gender ratio (M/F) & $60 \%$ & $82 \%$ & $80 \%$ & $83.33 \%$ & $75.21 \%$ \\
& $(21 / 35)$ & $(41 / 50)$ & $(16 / 20)$ & $(10 / 12)$ & $(88 / 117)$ \\
\hline
\end{tabular}

Ranks for education level: 1- Primary (up to G.C.E. O/L), 2- Secondary (up to G.C.E. A/L), 3- Diploma, 4- Degree

Table 2: Percentage application of recommended technologies in different farm sizes

\begin{tabular}{|c|c|c|c|c|c|c|c|c|c|c|c|c|c|c|c|c|}
\hline Land size & \multicolumn{4}{|c|}{$<2 \mathrm{Ac}$} & \multicolumn{4}{|c|}{$2.5 \quad$ Ac } & \multicolumn{4}{|c|}{ 5-20 Ac } & \multicolumn{4}{|c|}{$>20 \mathrm{Ac}$} \\
\hline Pest Species & $\begin{array}{l}\text { BB } \\
\%\end{array}$ & $\begin{array}{l}\text { RW } \\
\%\end{array}$ & $\begin{array}{l}\text { Mite } \\
\%\end{array}$ & $\begin{array}{l}\text { Plesi. } \\
\%\end{array}$ & $\begin{array}{l}\text { BB } \\
\%\end{array}$ & $\begin{array}{l}\text { RW } \\
\%\end{array}$ & $\begin{array}{l}\text { Mite } \\
\%\end{array}$ & $\begin{array}{l}\text { Plesi. } \\
\%\end{array}$ & $\begin{array}{l}\text { BB } \\
\%\end{array}$ & $\begin{array}{l}\text { RW } \\
\%\end{array}$ & $\begin{array}{l}\text { Mite } \\
\%\end{array}$ & $\begin{array}{l}\text { Plesi. } \\
\%\end{array}$ & $\begin{array}{l}\text { BB } \\
\%\end{array}$ & $\begin{array}{l}\text { RW } \\
\%\end{array}$ & $\begin{array}{l}\text { Mite } \\
\%\end{array}$ & $\begin{array}{l}\text { Plesi. } \\
\%\end{array}$ \\
\hline $\begin{array}{l}\text { Recommenda } \\
\text {-tion applied }\end{array}$ & $\begin{array}{l}65 \\
(13)\end{array}$ & $\begin{array}{l}31.58 \\
(6)\end{array}$ & $\begin{array}{l}13.33 \\
\text { (4) }\end{array}$ & $\begin{array}{l}16.67 \\
(2)\end{array}$ & $\begin{array}{l}73.17 \\
(30)\end{array}$ & $\begin{array}{l}64.29 \\
(27)\end{array}$ & $\begin{array}{l}42.11 \\
(16)\end{array}$ & $\begin{array}{l}76.19 \\
(16)\end{array}$ & $\begin{array}{l}93 \\
(13)\end{array}$ & $\begin{array}{l}61.11 \\
(11)\end{array}$ & $\begin{array}{l}31.25 \\
(5)\end{array}$ & $\begin{array}{l}63.64 \\
(7)\end{array}$ & $\begin{array}{l}81.82 \\
(9)\end{array}$ & $\begin{array}{l}58.33 \\
(7)\end{array}$ & $\begin{array}{l}33.33 \\
(3)\end{array}$ & $\begin{array}{l}66.67 \\
(6)\end{array}$ \\
\hline $\begin{array}{l}\text { Recommenda } \\
\text {-tion not } \\
\text { applied }\end{array}$ & $\begin{array}{l}35 \\
(7)\end{array}$ & $\begin{array}{l}68.42 \\
(13)\end{array}$ & $\begin{array}{l}86.67 \\
(26)\end{array}$ & $\begin{array}{l}83.33 \\
(10)\end{array}$ & $\begin{array}{l}26.83 \\
(11)\end{array}$ & $\begin{array}{l}35.71 \\
(15)\end{array}$ & $\begin{array}{l}57.89 \\
(22)\end{array}$ & $\begin{array}{l}23.81 \\
(5)\end{array}$ & $\begin{array}{l}7 \\
(1)\end{array}$ & $\begin{array}{l}38.89 \\
(7)\end{array}$ & $\begin{array}{l}68.75 \\
(11)\end{array}$ & $\begin{array}{l}36.36 \\
\text { (4) }\end{array}$ & $\begin{array}{l}18.18 \\
\text { (2) }\end{array}$ & $\begin{array}{l}41.67 \\
(5)\end{array}$ & $\begin{array}{l}66.67 \\
(6)\end{array}$ & $\begin{array}{l}33.33 \\
\text { (3) }\end{array}$ \\
\hline
\end{tabular}

*The figures in parenthesis are in number; BB- Black beetle, RW- Red weevil, Mite- Coconut mite, Plesi.- Plesispa beetle

Table 3: The level of technology adoption in different land categories to manage black beetles

\begin{tabular}{|l|l|l|l|l|l|l|}
\hline No. & \multirow{2}{*}{ Recommendation } & \multirow{2}{*}{ Method } & \multicolumn{4}{|c|}{ The level of Adoption (\%) } \\
\cline { 4 - 7 } & & & $\langle\mathbf{2 A c}$ & $\mathbf{2 - 5 A c}$ & $\mathbf{5 - 2 0 A c}$ & \multicolumn{2}{|c|}{$\mathbf{2 0 A c}$} \\
\hline 1 & Coal tar/Passed engine oil & Prevention & 55 & 63 & 64 & 55 \\
\hline 2 & Field sanitation/ Naphthalene balls & Prevention & 35 & 34 & 50 & 27 \\
\hline 3 & Metal hook & Control & 10 & 5 & 0 & 9 \\
\hline 4 & Carbofuran & Control & 40 & 51 & 21 & 64 \\
\hline 5 & Metarrhizium fungus & Control & 0 & 0 & 0 & 0 \\
\hline 6 & Use of pheromone traps & Control & 0 & 0 & 14 & 0 \\
\hline 7 & None & None & 30 & 27 & 29 & 18 \\
\hline
\end{tabular}


Table 4: The level of technology adoption to control red weevils in different land categories

\begin{tabular}{|c|l|l|c|c|c|c|}
\hline \multirow{2}{*}{ No. } & \multirow{2}{*}{ Recommendation } & \multirow{2}{*}{ Method } & \multicolumn{4}{c|}{ The level of Adoption (\%) } \\
\cline { 4 - 7 } & & & <2Ac & $\mathbf{2 - 5 A c}$ & $\mathbf{5 - 2 0 A c}$ & > 20Ac \\
\hline 1 & Use of Penthoate & Control & 11 & 24 & 33 & 17 \\
\hline 2 & Use of Monocrotophos & Control & 11 & 10 & 17 & 17 \\
\hline 3 & Routine examine & Prevention & 5 & 21 & 44 & 25 \\
\hline 4 & Coal tar/ Passed engine oil & Prevention & 32 & 55 & 28 & 25 \\
\hline 5 & Field sanitation & Prevention & 5 & 5 & 17 & 17 \\
\hline 6 & Use of pheromone traps & Control & 0 & 5 & 11 & 25 \\
\hline 7 & None & None & 68 & 33 & 33 & 42 \\
\hline
\end{tabular}

Table 5: The level of technology adoption in different land categories to manage coconut mite pest

\begin{tabular}{|c|l|l|c|c|c|c|}
\hline No. & \multicolumn{2}{|c|}{ Recommendation } & \multirow{2}{*}{ Method } & \multicolumn{4}{c|}{ The level of Adoption (\%) } \\
\cline { 4 - 7 } & & & <2Ac & $\mathbf{2 - 5 A c}$ & $\mathbf{5 - 2 0 A c}$ & $>$ 20Ac \\
\hline 1 & Remove and burn infested inflorescence & Control & 10 & 8 & 0 & 0 \\
\hline 2 & Use of Furnace oil & Control & 7 & 8 & 6 & 0 \\
\hline 3 & Use of palm oil/Sulfur mixture & Control & 3 & 29 & 13 & 33 \\
\hline 4 & Application of predator mite & Control & 0 & 16 & 6 & 22 \\
\hline 5 & None & None & 63 & 55 & 75 & 56 \\
\hline
\end{tabular}

Table 6: The level of technology adoption in different land categories to manage plesispa beetle

\begin{tabular}{|c|l|l|l|l|l|l|}
\hline No. & \multicolumn{2}{|c|}{ Recommendation } & \multirow{2}{*}{ Method } & \multicolumn{3}{c|}{ The level of Adoption (\%) } \\
\cline { 4 - 8 } & & & <2Ac & 2-5Ac & 5-20Ac & > 20Ac \\
\hline 1 & $\begin{array}{l}\text { Carbosulfan/Chloropyrifos/Marsha } \\
120\end{array}$ & Control & 17 & 76 & 64 & 67 \\
\hline 2 & None & None & 58 & 24 & 45 & 22 \\
\hline
\end{tabular}


Table 7: Perceived factors in adoption of technologies by farmers

\begin{tabular}{|c|c|c|c|}
\hline & $\begin{array}{l}\text { Recommendation } \\
\text { applied/not }\end{array}$ & $\begin{array}{l}\text { Information } \\
\text { received }\end{array}$ & $\begin{array}{l}\text { Damage } \\
\text { occurrence }\end{array}$ \\
\hline \multicolumn{4}{|l|}{ For Black beetle } \\
\hline \multirow{3}{*}{$\begin{array}{l}\text { Pearson correlation } \\
\text { Sig. (2-tailed) } \\
\mathrm{N}\end{array}$} & 1 & $0.366 * *$ & $0.520 * *$ \\
\hline & & 0.000 & 0.000 \\
\hline & 117 & 117 & 117 \\
\hline \multicolumn{4}{|l|}{ For Red Weevil } \\
\hline \multirow{3}{*}{$\begin{array}{l}\text { Pearson correlation } \\
\text { Sig. (2-tailed) } \\
\mathrm{N}\end{array}$} & 1 & $0.314 * *$ & $0.699 * *$ \\
\hline & & 0.001 & 0.000 \\
\hline & 117 & 117 & 117 \\
\hline \multicolumn{4}{|l|}{ For Coconut Mite } \\
\hline \multirow{3}{*}{$\begin{array}{l}\text { Pearson correlation } \\
\text { Sig. (2-tailed) } \\
\mathrm{N}\end{array}$} & 1 & 0.054 & $0.661 * *$ \\
\hline & & 0.567 & 0.000 \\
\hline & 117 & 117 & 117 \\
\hline \multicolumn{4}{|l|}{ For Plesispa Beetle } \\
\hline \multirow{3}{*}{$\begin{array}{l}\text { Pearson correlation } \\
\text { Sig. (2-tailed) } \\
\mathrm{N}\end{array}$} & 1 & $0.290 * *$ & $0.868 * *$ \\
\hline & & 0.001 & 0.000 \\
\hline & 117 & 117 & 117 \\
\hline
\end{tabular}

**Correlation is significant at the 0.001 level (2-tailed)

Table 8: Perceived constraints to non adoptability of recommended technologies

\begin{tabular}{|c|l|l|l|l|l|}
\hline No. & Perceived constraints & $\begin{array}{c}\text { Black beetle } \\
\text { \% }\end{array}$ & $\begin{array}{c}\text { Red Weevil } \\
\text { \% }\end{array}$ & $\begin{array}{c}\text { Coconut } \\
\text { mite } \\
\%\end{array}$ & $\begin{array}{c}\text { Plesispa } \\
\text { beetle } \\
\%\end{array}$ \\
\hline 1 & $\begin{array}{l}\text { Unawareness of } \\
\text { technologies }\end{array}$ & 22.99 & 28.99 & 39.8 & 24.6 \\
\hline 2 & $\begin{array}{l}\text { Low attention for } \\
\text { coconut farming }\end{array}$ & 26.44 & 41.11 & 58.16 & 31.15 \\
\hline 3 & Poor economic status & 2.3 & Not indicated & 6.12 & Not indicated \\
\hline 4 & Shortage of chemicals & Not indicated & 36.67 & Not indicated & Not indicated \\
\hline
\end{tabular}


Extent of technology adoption in different land categories to manage red weevil pest problem is shown in table 4.

The table 4 explains that 55 percent growers in 2-5Ac land category have adopted to "apply coal tar or passed engine oil on freshly making wounds on trunks and petioles of all young palms" as a preventive method against red weevils. Although 33\% growers in 5-20Ac land category were used Penthoate $500 \mathrm{EC}$ as a trunk injection. $17 \%$ growers in 5-20Ac and >20Ac land categories were adopted for monocrotophos chemical injection method.

It was revealed that only 25 percent growers in $>20$ Ac category have adopted to use pheromone traps to control red weevils and it was $11 \%$ and $5 \%$ in $5-20 \mathrm{Ac}$ and $2-5 \mathrm{Ac}$ categories respectively. And also, it was noted that more than $33 \%$ growers in all land categories have not adopted the technologies developed by the CRI (Table 4).

The table 5 explains that, the level of technology adoption to control coconut mites in different land categories.

It was observed that $33 \%$ and $22 \%$ growers in $>20 \mathrm{Ac}$ land categories have adopted to apply palm oil/sulfur mixture and predatory mite respectively. However, more than 55\% growers in all land categories have not adopted any of the technologies introduced by the CRI to manage coconut mite in their fields.

The level of technology adoption in different land categories to manage plesispa beetles is shown in table 6 .

It was noted that the majority of the growers (more than 60\%) in all land categories except <2Ac category have adopted the recommended techniques to control plesispa beetles.

It was revealed that that the decision making on the adoption of different technologies is affected by the perceptions of the growers. Growers' perception was significantly determined by two factors, information receiving sources and occurrence of pest attacks in their fields (Table 7).
The data in respect of perceived constraints indicated in table 8 revealed that unawareness of technologies and low attention for coconut farming was the two major reasons for poor adoption of the recommended technologies.

\section{Conclusion}

The findings of the study revealed that more than 70 percent of the growers in all land categories except $<2 \mathrm{Ac}$ land category have adopted technologies recommended by the CRI to control black beetles. Technology adoption for control red weevil is around 60 percent, for coconut mite it is around 30 percent and for plesispa beetle it is around 65 percent.

It also reveals that more than 55 percent growers in all land categories have not adopted any of the technologies introduced by the CRI to manage coconut mite as growers are not much aware of the spraying of palm oil/sulfur mixture and their inability of buying predatory mite bags. The information receiving sources and occurrence of a pest attack determines the grower's perception. The unawareness of technologies and low attention for coconut farming are the two major reasons for nonadoptability of recommended technologies. And also, younger generation's participation is very poor in coconut cultivation at presence. This may be the result of deviation of teenagers in seeking reputed and respective jobs in the society without being a "farmer".

The coconut growers in Kurunegala district require more awareness regarding recommended plant protection technologies to manage major coconut pests. For that purpose, farmer level extension programmes should be strengthened.

\section{Acknowledgement}

I would like to express my sincere gratitude to the Director, Additional Director and Deputy Director (Research) of the Coconut Research Institute of Sri Lanka for giving permission to carry out this study. 


\section{References}

Akhilesh K. Dubey and J.P. Srivastava (2007). Effect of training programme on knowledge and adoption behaviour of farmers on wheat production technologies. Indian Res. Ext. Edu., 7(2\&3): 41-43

Basaram, G. S. and Cofenor, A. R., (1968). Factors related to acceptance of new ideas and techniques in farming Punjab. Indian Journal of Extensional Education, 4(1 and 2): 29-39.

Central Bank Report of Sri Lanka, 2016: Chapter 6 (2), 39-45.

Coconut Statistics, 2008. Ministry of Plantation Industry, Colombo 2, Sri Lanka.

Fernando, L.C.P., Manoj, P., Hapuarachchi, D.C.L., Edgington, S. (2007). Evaluation of four isolates of Hirsutella thompsonii against coconut mite (Aceria guerreronis) in Sri Lanka. Crop Protection 26: 10621066.

Ghulam Ali Jariko., Mumtaz Ali Junejo., Muhammad Saleem Rahpoto., Maqsood Zia Shah., 2011. Socioeconomic factors affecting adoption of Sunflower varieties in Sindh. Pakistan Journal of Commerce and Social Sciences. Vol. 5 (1), 192-201.

Liyanage, M. de S. (1999) A guide to scientific cultivation and management of coconut, Hitech Prints, Nugegoda Sri Lanka.
Peiris, T.S.G., Appuhamy, P.A.H.N., Nainanayake, N.P.A.D., Bandaranayake, C.K. and Fernando, M.T.N. (2006). Coconut research, development and dissemination of technologies - Growers perception. A diagnostic survey report, coconut Research Institute, Lunuwila, Sri Lanka: 33-77.

Ranasinghe, C.S., Peiris, T.S.G., Jayawardena, J., Perera, L., Fernando, M.T.N. and Wickramananda, I. (2006). Coconut palm decline: Assessment of the prevalence and probable causes. A CRI Publication.

Rogers, E. M., (1968). Diffusion of Innovations. Free Press, New York.

Somasiri, L.L.W., Nadarajah, N., Amarasinghe, L. and Gunathilake, H.A.J. (1994). Land suitability assessment of coconut growing area in the coconut triangle. Occasional Publication Series 3, CRI, Lunuwila.

Statistics on coconut and oil palm. 1, 2011. Coconut Research Institute, Lunuwila, Sri Lanka; 18.

Wickramananda, I.R., Peiris, T.S.G., Neil Fernando, M.T., Fernando, L.C.P. and Edgington, S. (2007) Impact of the coconut mite (Aceria guerreronis Keifer) on the coconut industry in Sri Lanka. Cord 23 (1). 